\title{
A Missing Fibich Autograph Found in Vienna
}

\author{
Jan Kachlík
}

I came upon the autograph of a short piano piece by Zdeněk Fibich titled Sarabanda thanks to research pertaining to Antonín Dvořák, ${ }^{1}$ because the genesis of and sources for this piece by Fibich are very closely connected with another twelve short pieces by his contemporaries including Dvořák. Early in 1881 the Hudební odbor Umělecké besedy [Music Section of the Artists' Society] in Prague decided to prepare an album of pieces by Czech composers to be dedicated to Crown Prince Rudolf of Austria and Crown Princess Stephanie, as a gift on the occasion of their wedding. The composers chosen, in alphabetical order, were Karel Bendl, Antonín Dvorák, Zdeněk Fibich, Josef Foerster, Emanuel Chvála ("ch" following "h" in the Czech alphabet), Karel Knittl, Karel Kovařovic, Pavel Křržžkovský, Václav Juda Novotný, František Pivoda, Josef Richard Rozkošný, František Zdeněk Skuherský, and Bedřich Smetana. The pieces were arranged in this order in the album.

Before focusing on the autograph of the Sarabanda, let us take a look at its first printed edition, in an album containing a total of thirteen pieces issued by the Prague publishing house of Emanuel Starý. The cover bears a long, exalted title: Slavnostni album jejich císařským výsostem korunnímu princi Rudolfovi a arcikněžně Stefanii na památku sňatku jejich $[\ldots]^{2}$ The print bears no date, but from other sources we can reliably date it to 1882 , indeed more precisely to May of that year. ${ }^{3}$ Although the title page includes the year 1881, that is not the date of issue of the print but rather part of the dedication, referring to the

1 The present study came into being as part of a grant project, Nové souborné vydání děl Antonína Dvořáka. Pramenný výzkum a edični príprava vybraných svazků [The New Complete Edition of the Works of Antonín Dvořák: Source Examination and Editorial Preparation of Selected Volumes], GA408/08/1020, whose principal investigator is Jarmila Gabrielová.

2 Celebratory Album Given to Their Imperial Highnesses Crown Prince Rudolf and Archduchess Stephanie in Commemoration of Their Wedding [...].

3 Concerning the dating of the printed edition see Dalibor, 4 (1882), No. 12, p. 95 and Dalibor, 4 (1882), No. 16, p. 128. Dating of prints issued by Emanuel Starý is often difficult, because like many other publishers of his time he issued a large portion of his publications without date. 
exact date of the wedding: "K RADOSTNÉMU DNI X. KVĚTNA MDCCCLXXXI" [FOR THE JOYFUL DAY 10 MAY 1881].

Although the genesis of the Artists' Society's album can be reconstructed based on reports in periodicals of the time, descriptions of this edition in the professional literature are very inadequate. At first it would seem that only the dating of the print is insufficient, but actually the problem is more serious. The print is usually dated-in square brackets or sometimes without them-either to 1881 , i.e. the year of the wedding, or to 1882, i.e. the actual year of issue. More than once we even find both datings within a single publication. ${ }^{4}$

Why this double dating of the print? It has persisted in modern literature for a surprisingly long time. After all, the history of the album's genesis is captured in detail in the journal Dalibor, whose editor at that time, Václav Juda Novotný, was also one of the thirteen composers contributing to the album. ${ }^{5}$ The first report in Dalibor appeared in the issue of 20 April 1881:

To celebrate the wedding of His Imperial and Royal Highness Crown Prince Rudolf and the most radiant Princess Stephanie, the Music Section of the Artists' Society in Prague will present to Their Highnesses a splendid album planned to contain one piece each by foremost Czech composers, who have already been invited for this purpose by a special committee. All the pieces (variously for piano, for harmonium, for voice with piano accompaniment, and for male vocal quartet) will of course remain the property of the exalted betrothed couple, and the Artists' Society will see to their dignified publication and dissemination only with Their explicit permission. ${ }^{6}$

This was a "splendid album" in the true sense of the word, because it contained the autograph manuscripts of the pieces-as confirmed by the following two reports from June 1881:

The Music Section of the Artists' Society will present a gift to Their Highnesses Crown Prince Rudolf and Crown Princess Stephanie as a tribute which will cer-

4 An example is the 1955 critical edition of Dvořák's Moravian Duets. The foreword by Otakar Šourek tells us "[The duet] 'Na tej našej střeše' appeared as the second number in the 'Slavnostní album', published in 1881 by the Umělecká Beseda in Prague (for details see the Editors' Notes) [...]”. But elsewhere in the same volume the author of the Editors' Notes Antonin Čubr states that "the Album was published by Em. Starý in April 1882". See Antonín Dvořák: Complete Edition. Moravian Duets, $O p .20,32,38$, Prague 1955, pp. VII and [103]. (In a revised version of this edition from 1962 the year 1881 in the foreword is corrected to 1882.) In the catalogue of Fibich's works the two conflicting dates even occur in direct proximity: the printed Slavnostni album is dated first to 1881, then at a different point in the same brief catalogue entry to 1882; see Vladimír Hudec, Zdeněk Fibich. Tematický katalog [Zdeněk Fibich: Thematic Catalogue], (Prague, 2001), p. 269.

5 Novotnýs Allegretto à la Polka for violin with piano accompaniment is placed in the album as number IX.

6 Dalibor, 3 (1881), No. 12, p. 94. 
tainly be of great importance. It is an album of pieces composed specially for this purpose, in the composers' own manuscripts. ${ }^{7}$

Besides the dedication page, executed with tasteful simplicity, this Memorial comprises thirteen sheets containing as many pieces by leading Czech composers, all of them original works composed specially with this intent, each occupying the front side of one sheet in large quarto format-entirely as autograph manuscripts. The pieces are written by the composers on deluxe paper on staves with blue lines $[\ldots]^{8}$

Then in April of the following year, 1882, again on the pages of Dalibor, in its "Overview of Musical Activities in Bohemia in 1881", the executive agent of the Music Section of the Artists' Society Antonín Mikenda mentions not only the album of autographs but preparations for its issue in printed form:

Finally we may boast of a Commemorative Album, which the Music Section of the Artists' Society has presented to the exalted betrothed couple; [...] soon [these pieces] will reach the public through a printed reproduction arranged for by the Artists' Society, published by Em. Starý $[\ldots]^{9}$

Thus it is essential to distinguish between two completely different sources: the gift from 1881 and the print issued a year later in May 1882. Whereas in the first case we must speak of an autograph album (according to the various designations used at the time a Commemorative or Memorial Album, or a Memorial), containing autographs including that of the Sarabanda by Zdeněk Fibich, in the second case we are dealing with a print, more precisely a first print, titled Slavnostní album (Celebratory Album).$^{10}$ This edition was produced in two different forms of print treatment which differed both in appearance and in price. The cheaper version was sold for " $1 \mathrm{zl} .50 \mathrm{kr}$." ( 1 zlatý, i.e. florin or gulden, and 50 krejcars, i.e. kreuzers, in "konvenční měna", i.e. conventional currency), and the more expensive, "deluxe” one for " 3 zl. r. č." (3 florins "rakouského čísla”, i.e. "Austrian number" meaning the new Austrian currency). ${ }^{11}$ By contrast with the cheaper edition,

7 Dalibor, 3 (1881), No. 16, p. 127.

8 Dalibor, 3 (1881), No. 17, p. 135.

9 Dalibor, 4 (1882), No. 11, p. 85, under “Přehled činnosti hudební v Čechách roku 1881". The first report of preparations for the printed version of the album had appeared in Dalibor already on 20 February 1882.

10 Slavnostní album Jejich cís. výsostem korunnímu princi Rudolfovi a arcikněžně Stefanii na památku sňatku jejich věnované Uměleckou besedou v Praze [Celebratory Album Given to Their Imperial Highnesses Crown Prince Rudolf and Archduchess Stephanie in Commemoration of Their Wedding by the Artists' Society in Prague], Em. Starý, Prague [May 1882]; facsimile of the cover, title page, and Dvořák’s duet "Na tej našej střeše” in Jan Kachlík, Hledání autenticity: Dvořákovy Moravské dvojzpěvy a historie jejich vydávání [The Search for Authenticity: Dvorák's Moravian Duets and the History of Their Publication], (Prague, 2009), p. 180-182.

11 See Dalibor, 4 (1882), No. 16, p. 128. 
printed on both sides of the sheets, only the front sides of the sheets are printed in the more expensive version, while the opposite page (the back side of the previous sheet) is left blank. Moreover, the more expensive version has a larger format with more generous margins, and paper of higher quality with greater weight. The intent of the more expensive edition was to approach at least partly the appearance of the original autograph album. However, there is no difference between the two printed versions in the musical notation. ${ }^{12}$

As mentioned above, I searched for and found the autograph album in connection with Dvořák research. This despite the fact that a copy of Dvořák's own autograph in the album was already available to researchers. The second edition of Jarmil Burghauser's thematic catalogue, from $1996,{ }^{13}$ gives a reference to the Nationalbibliothek in Vienna including the shelfmark of the autograph. ${ }^{14}$ However, because he does not associate Dvořák's autograph with the whole autograph album it is clear that Burghauser himself never saw it, and only received a copy of one page (the Dvoŕák page) with reference to the shelfmark. This shelfmark in fact applies not just to the one sheet, but to the whole album with all thirteen autographs including Fibich's.

Therefore one could now correct the information about this previously-missing autograph source in the catalogues of works of all the remaining twelve composers-except that, as is well known, most of these composers have no catalogue. In this respect Fibich is among the more fortunate. However, adding to the information in the Hudec catalogue of his works ${ }^{15}$ will not be merely a mechanical matter.

Fibich is represented in the album (under number III) by his Sarabanda, a single-page piece for piano in the key of $\mathrm{g}$ minor-without further specification. In the Hudec catalogue this Sarabanda does not have a separate catalogue number, but rather is included as the fourth movement of the Suite in $g$ minor under catalogue number $222 .{ }^{16}$ This suite is shown in the catalogue as having five movements. It has never been published in its entirety, and for the whole suite we find the summary annotation: autograph unknown. So can we now merely add our new information, saying that the autograph for the fourth movement, the Sarabanda, is deposited in the Nationalbibliothek in Vienna and that the

12 Most of the specimens found in Prague collections so far are of the edition costing 1,50 florins. It is found in the music department of the Prague Municipal Library under shelfmark VZ 47120, the music department of the National Library of the Czech Republic under shelfmark 59 A 8793, the archive of the Prague Conservatory under shelfmark 3 D 10769, and the music archive of the Czech Museum of Music (of the National Museum) under shelfmark IV A 7. We know of only one specimen of the more expensive edition, which moreover is not complete, preserved in the papers from Dvořák's estate in the Antonín Dvořák Museum (of the Czech Museum of Music, of the National Museum) under inventory number S 226/1406, SAD 138.

13 Jarmil Burghauser, Antonín Dvořák. Thematický katalog [Antonín Dvořák: Thematic Catalogue], $2^{\text {nd }}$ ed., (Prague, 1996), p. 208.

14 SN 2152 (correctly: Mus. Hs. 2152).

15 Vladimír Hudec, Zdeněk Fibich. Tematický katalog (Prague, 2001).

16 Ibid., p. 269. 


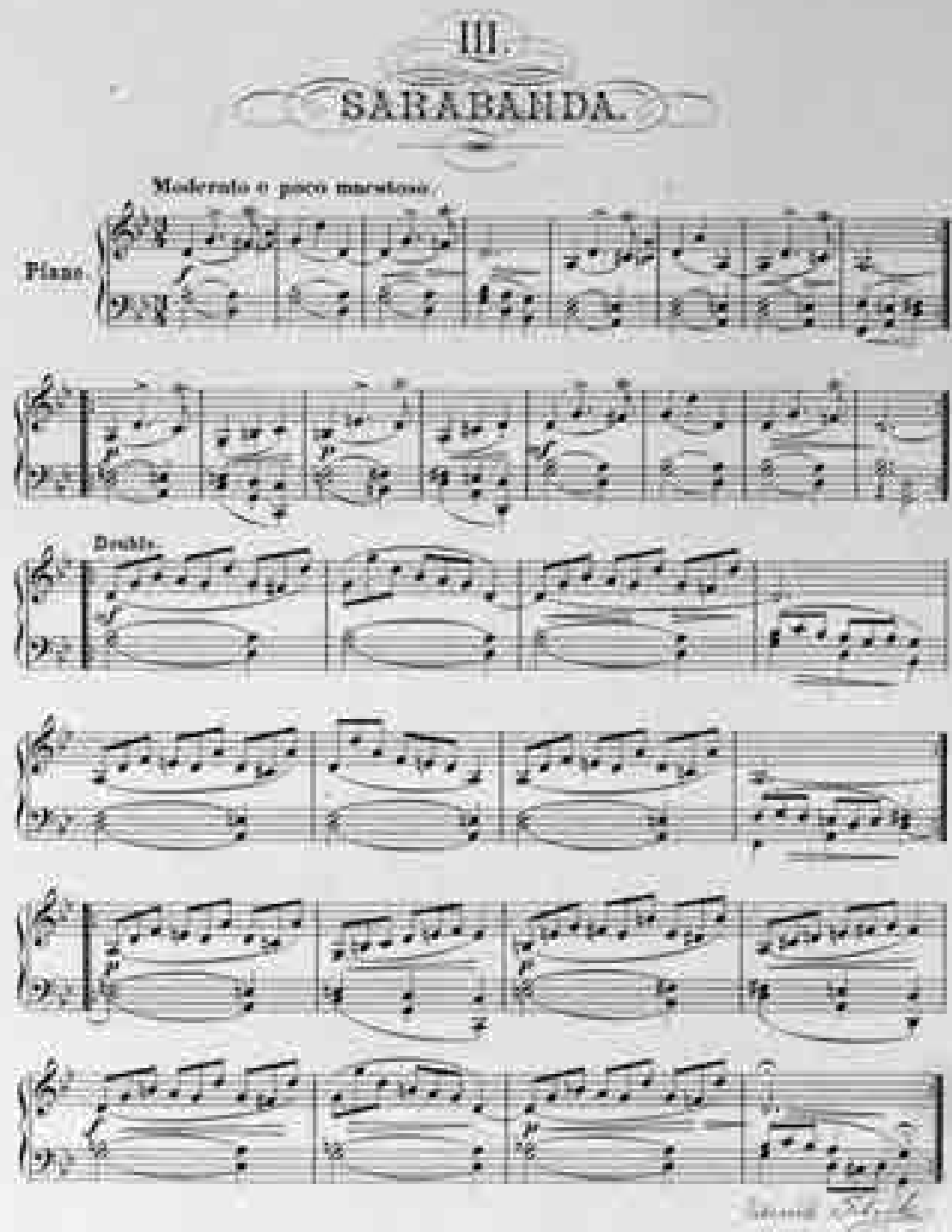

Example 1: First edition of the Sarabanda, number 3 in the Slavnostni album [Celebratory Album], Em. Starý, Prague [1882]; specimen from the estate of Antonín Dvorák, Antonín Dvořák Museum (of the Czech Museum, of the National Museum) in Prague, inventory number S 226/1406, SAD 138 
autographs for the remaining movements remain missing? No, because the source situation is somewhat more complicated.

Let us now return to the autograph album and the activities of the Music Section of the Artists' Society associated with the origin of this gift. From the reports in Dalibor we know about "foremost Czech composers, who have already been invited for this purpose by a special committee.” This committee was represented by the Artists' Society's executive agent Antonín Mikenda. Perhaps the letter Mikenda sent to Fibich will be found some day, but in any case it was probably very similar if not identical to the one received by Smetana and preserved in the papers from his estate, written 7 April 1881-perhaps on the same day as the letter to Fibich. It reads in part:

We call upon you, revered sir, to be so kind as to play a role, certainly dignified, in the noble purpose with one piece (a piece for piano) in the Music Section's memorial [book] and not to consider it burdensome to send this piece to us no later than by the last day of April this year for examination, so that we might send you splendid paper with staff lines drawn specially for each piece, sufficiently far in advance that you might write it there in your own hand. Let the piece be specially composed for this purpose and nowhere, in no way, published either earlier or later; it should also form a complete whole in itself, because excerpts and fragments are absolutely out of the question.

However, because only one page in quarto format can be devoted to each piece-the other side of the sheet remaining empty-we ask that you be so kind as to keep this in mind while composing; $[\ldots]^{17}$

And how did Fibich respond to these specifications from the committee? It seems that he made use of his Suite in $g$ minor, all of whose movements according to Moser $^{18}$ and also according to Hudec's catalogue were composed almost four years earlier in 1877, choosing from it the most suitable movement for the purpose of the album, the Sarabanda, and adapting it, mainly by shortening it somewhat. Moser's catalogue (Example 2) gives the number of its bars as 48, whereas the number of bars in the adapted version in the album is only 32 .

17 Antonín Mikenda (representing the Artists' Society in Prague) to Bedřich Smetana, Prague, 7 April 1881; original deposited in the Bedřich Smetana Museum (of the Czech Museum of Music, of the National Museum) under inventory number S 217/1049. I thank Olga Mojžíšová, head of the Smetana Museum, for bringing this previously-unpublished letter to my attention and for providing a transcription thereof, from which I quote (including underlining, etc).

18 I thank Jiři Kopecký very much for kindly making available copies of the relevant pages (126-127) of Moser's catalogue, existing only in manuscript; the original is in a private collection. 


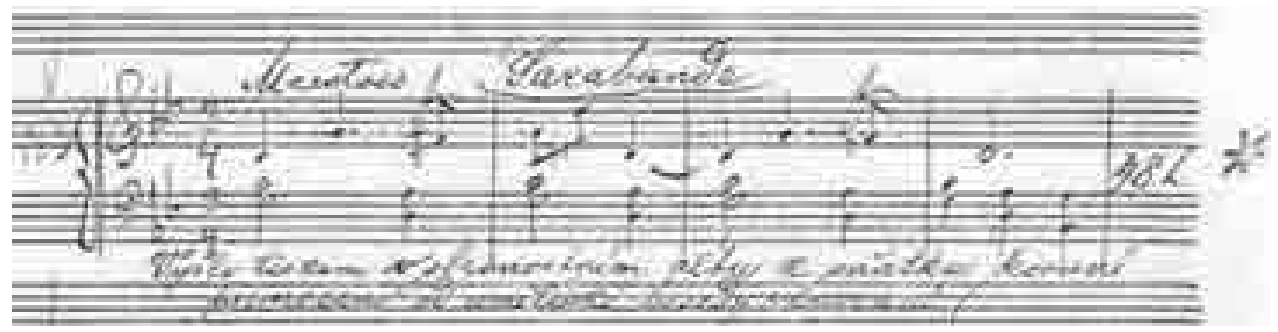

Example 2

Fibich may have increased the number of repetitions as compared with the original version; in any case he now uses them to the greatest possible extent. He changed other parameters as well, as evident from the incipit in Moser's catalogue (see above). This pertains for example to the tempo marking, which he changed from the original Maestoso shown in Moser's catalogue to Moderato e poco maestoso in the Vienna autograph (cf. p. 126).

One of the above-cited articles-the one published in the 10 June 1881 issue of Dalibor-discusses the Artists' Society album of autographs more extensively. The author, signed by the insignia “(M.)”, probably Antonín Mikenda, says of Fibich's Sarabanda:

The unusual title may surprise us and even seem somewhat peculiar, but let us just sit down with relish to the piano, and after the first bars we'll certainly be good friends with this dance-which, somewhat reminiscent of a minuet, moves with even greater "grandezza" in a slow tempo. It is truly amazing how easily Fibich was able to empathize with its special character (having gone for this gift of his all the way to Spain and to old French masters!), and this attests to the excellent flexibility and the accommodating strength of his spirit. It is an elegant piece, of an aristocratic cast. ${ }^{19}$

The discovery of Fibich's missing autograph and its placement in the context of other relevant sources allow us to draw the following conclusions. If Moser's dating of the Sarabanda and the whole Suite in $g$ minor is based on sources, then we can say that in April 1881 Fibich created a new, somewhat shorter version of a piece written in his earlier autograph from 1877, and sent it for assessment to the committee of the Music Section of the Artists' Society. Finally he wrote the Sarabanda on splendid paper delivered to him by the committee. Thus the Vienna autograph should be chronologically the third of Fibich's autograph notations of this piece. In other words: while reporting the discovery of Fibich's

19 Dalibor, 3 (1881), No. 17, p. 135. 


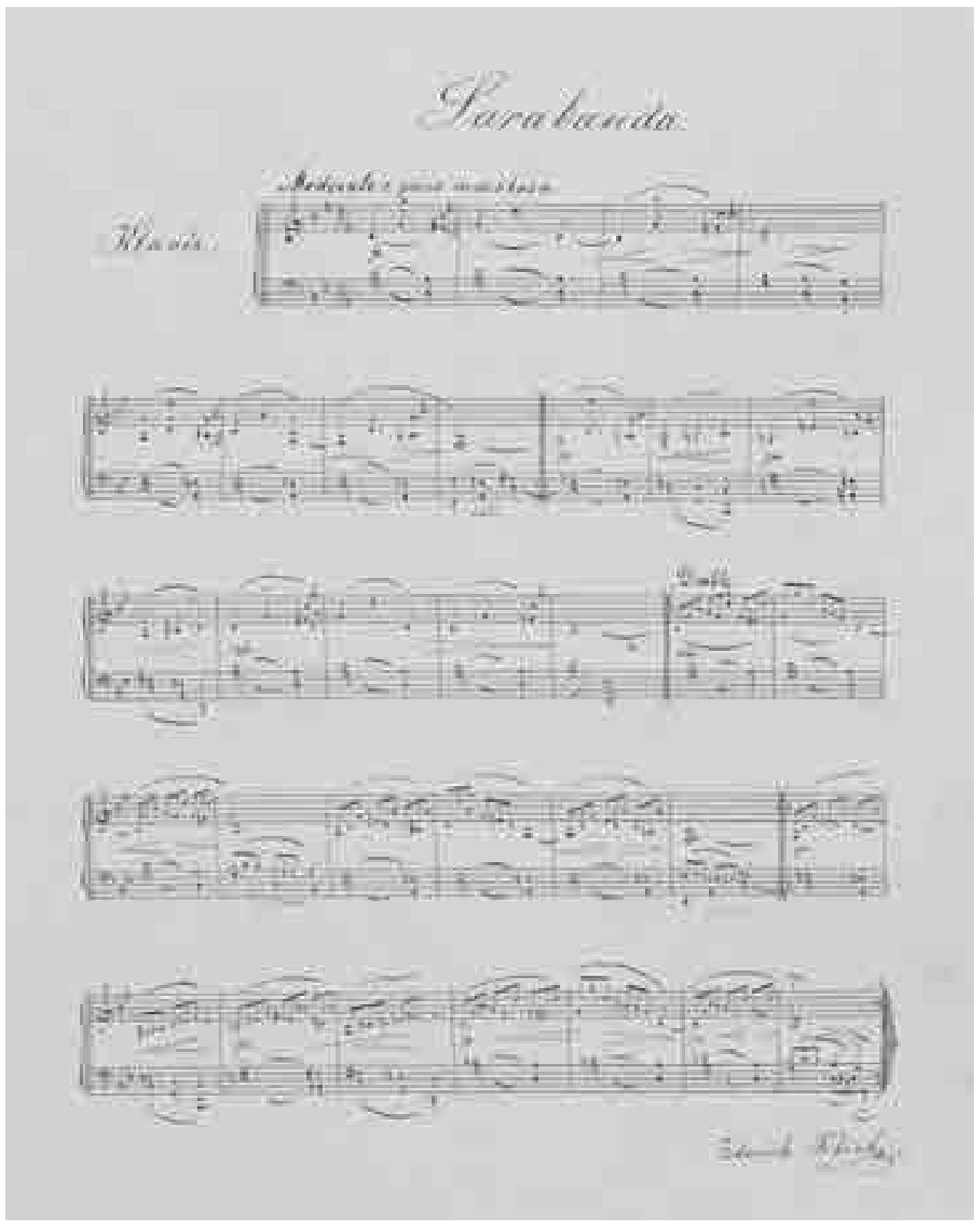

Example 3: Autograph of the Sarabanda in the autograph album, folio 4, Österreichische Nationalbibliothek in Vienna, Musiksammlung, shelfmark Mus. Hs. 2152 
autograph we must also observe that we still lack two other autographs in the set of sources for this short piano piece, preceding the autograph fair copy that is the subject of this study.

Translated by David R. Beveridge

\title{
Fibichs verschollenes Autograph in Wien gefunden
}

\begin{abstract}
Zusammenfassung
Im Rahmen der Forschung bezüglich der Neuen Gesamtausgabe der Werke von Antonín Dvořák gelang es, eine verschollene autographe Niederschrift Fibichs zu finden. Es handelt sich um einen Bestandteil des Widmungsbands der Musiksektion des Künstlervereins Umělecká beseda in Prag an Kronprinz Rudolf und Kronprinzessin Stephanie, der ihnen 1881 als Hochzeitsgeschenk übergeben wurde. Das Album umfasst kleine einseitige Kompositionen von dreizehn böhmischen Komponisten, wobei jede mit der Hand ihres Komponisten geschrieben wurde. Im Falle Fibichs handelt es sich um die Sarabanda aus der Suite g-Moll, Hud 222. Die Studie beschäftigt sich mit der Genese des Widmungsbands sowohl in dessen autographer als auch in dessen gedruckter Form (Praha 1882). Die Umstände der Entstehung der kleinen Gelegenheitskomposition Fibichs werden vom Autor der Studie auf Grund einiger relevanter Quellen rekonstruiert, wobei auch die Existenz weiterer, heute allerdings verschollener Quellen belegt wird.
\end{abstract}

\section{Nezvěstný Fibichův autograf nalezen ve Vídni}

\section{Shrnutí}

V rámci výzkumu spojeného s Novým souborným vydáním děl Antonína Dvořáka se podařilo nalézt jeden nezvěstný autografní zápis Fibichův. Je součástí pamětního alba, které v roce 1881 předal Hudební odbor Umělecké besedy korunnímu princi Rudolfovi a korunní princezně Stefanii jako dar k jejich sňatku. Album obsahuje krátké jednostránkové skladby třinácti českých skladatelů, zapsané vždy rukou svého autora. V prrípadě Fibichově se jedná o Sarabandu ze Suity g moll, Hud 222. Studie se stručně zabývá genezí alba jak v jeho autografní, tak i v tištěné podobě (Praha 1882). Okolnosti vzniku Fibichovy krátké příležitostné skladby autor studie rekonstruuje na základě několika relevantních pramenů a dokládá tak existenci dalších, nyní však nezvěstných pramenů. 


\section{Keywords}

Zdeněk Fibich; piano music; Sarabanda from the Suite g minor. 